\title{
ODREDNICE ODANOSTI LOKALNOG STANOVNIŠTVA PREMA MARKI TURISTIČKE DESTINACIJE
}

\author{
Marijana Jurišić
}

Univ. spec. oec. doktorand, Fakultet za menadžment u turizmu i ugostiteljstvu, Sveučilište u Rijeci, Primorska 42, 51410 Opatija, Hrvatska; e-mail: marijana1308@gmail.com

\section{Jasmina Dlačić}

Dr. sc., docent, Ekonomski fakultet u Rijeci, Sveučilište u Rijeci, Ivana Filipovića 4, 51000 Rijeka, Hrvatska; e-mail: jasmina.dlacic@efri.hr

\section{Bruno Grbac}

Dr. sc., profesor emeritus, Sveučilište u Rijeci, Hrvatska; e-mail: bruno.grbac.efri@gmail.com

\section{SAŽETAK}

Uspješan razvoj turističke destinacije determiniran je proaktivnim djelovanjem svih njenih dionika. Ključni dionici turističke destinacije su, pored turista, zaposlenici u turizmu, poslovni subjekti u turizmu kao nositelji turističke ponude, lokalna samouprava, investitori u turističke sadržaje i lokalno stanovništvo. U radu se polazi od postavki da je lokalno stanovništvo zaposleno u turizmu ključni čimbenik koji pridonosi izgradnji prepoznatljivosti destinacije i njene diferencijacije u odnosu na druge turističke destinacije. Na osnovi rezultata prošlih istraživanja i istraživanja na terenu ispituje se kojim mehanizmima lokalno stanovništvo, a posebno oni koji djeluju i zaposleni su u turizmu, pridonose izgradnji marke turističke destinacije. $U$ tu surhu provedeno je ispitivanje putem anketnog upitnika na namjernom uzorku u više turističkih destinacija u Hrvatskoj. Utvrđeno je da svijest o marki turističke destinacije pozitivno utječe na percipiranu vrijednost marke turističke destinacije te da percipirana vrijednost marke turističke destinacije pozitivno utječe na odanost prema marki turističke destinacije, što u konačnici utječe na razvoj marke destinacije. Rad nije istražio sve utjecajne veličine na stvaranje marke turističke destinacije, u čemu je njegovo ograničenje, ali je ukazao na nova područja istraživanja i potencijal ponuđenih rezultata za upravljačke strukture u turizmu u izgradnji marke turističke destinacije.

Ključne riječi: marka turističke destinacije, lokalno stanovništvo, svijest marke, percipirana vrijednost marke, odanost marke 


\section{UVOD}

Razvoj turističke destinacije determiniran je odnosom turističke potražnje i turističke ponude na određenom prostoru. Prostor je fizički okvir sa svim prirodno-geografskim obilježjima. Na turističku atraktivnost prostora pored prirodno-geografskih obilježja utjecaj dolazi od aktivnosti države, gospodarstva, društva i, posebno, lokalnog stanovništva. Prostori zbog navedenih osobitosti i aktivnosti postaju više ili manje atraktivne turističke destinacije. Javlja se potreba za razvojem onih karakteristika koje jednu destinaciju odvajaju od druge i koje jačaju njenu konkurentnost. $U$ tome materijalne i duhovne vrijednosti lokalnog stanovništva određenom prostoru - turističkoj destinaciji daju novu dimenziju. Lokalno stanovništvo, posebno ono zaposleno u turizmu, determinira prostor, omogućuje oblikovanje turističke destinacije i usavršavanje imidža turističke destinacije. U cilju da određena turistička destinacija kontinuirano ostvaruje konkurentsku prednost potrebno je dobar imidž destinacije realizirati izgradnjom marke destinacije. $U$ tome je ključna uloga lokalnog stanovništva zaposlenog u turizmu. Naime, lokalno stanovništvo, a posebno zaposleni u turizmu, prvi su u izravnom kontaktu s turistima, turoperatorima i drugim turističkim agencijama, a dojam iz prvog kontakta ima posebnu težinu i utjecaj na dobar imidž i razvoj marke destinacije.

Dakle, lokalno stanovništvo zaposleno u turizmu sastavnica je prostora turističke destinacije te utječe na imidž i izgradnju marke turističke destinacije. Iz navedenoga proizlazi svrha rada - spoznati utjecaj lokalnog stanovništva zaposlenog u turizmu na razvoj destinacije. Cilj rada je istražiti ulogu zaposlenih u turizmu kao dijela lokalnog stanovništva u izgradnji marke turističke destinacije.

Rad je podijeljen u četiri cjeline. Nakon uvoda slijedi analiza prethodnih istraživanja vezanih uz marku i ulogu lokalnog stanovništva u izgradnji marke. Zatim se postavljaju hipoteze koje će se u empirijskome dijelu rada na primjeru destinacija u Hrvatskoj i testirati. U nastavku se elaboriraju najznačajniji rezultati istraživanja i njihov doprinos. Na kraju se rezimiraju rezultati istraživanja, navode ograničenja u istraživanju, ističu prijedlozi za nova istraživanja i sugestije za marketinške menadžere $\mathrm{u}$ turizmu $\mathrm{i}$ kreatore politike $\mathrm{u}$ turizmu.

\section{ANALIZA PROŠLIH ISTRAŽIVANJA I POSTAVLJANJE HIPOTEZA}

Američka udruga za marketing (AMA) marku definira kao ime, izraz, simbol, dizajn, ili njihovu kombinaciju, koja identificira proizvod ili uslugu jednog proizvođača, ili grupe proizvođača, te ga diferencira od konkurencije (AMA, 2017). Marka može biti kreirana i namijenjena proizvodu i uslugama, poslovnim subjektima, ali i za određenu destinaciju. Tako marku destinacije čini ime, simbol, logo, riječ, oznaka ili drugi grafički znak koji u isto vrijeme identificira destinaciju i čini je različitom od drugih (Brent-Ritchie, 1998:89).

Marka destinacije je puno kompleksnija i složenija u odnosu na marku proizvoda ili usluge jer uključuje puno više dionika i kontrola marke destinacije nije pod kontrolom marketinških stručnjaka (Blichfeldt, 2005:392). Iste stavove dijele Gartner i Konecnik Ruzzier (2011) koji također smatraju da postoje razlike između karakteristika marke destinacije i marke klasičnih proizvoda ili usluga. 
Oni ističu da destinacije nisu statične, odnosno, da se konstantno mijenjaju, bilo radi klimatskih prilika u određenom dijelu sezone, radi promjena u prostoru zbog novih turističkih kapaciteta, promjena u strukturi stanovništva ili nekih drugih promjena. Isti autori nadalje ističu da se ključna karakteristika marke destinacije temelji na doživljaju i da svaki posjetitelj na drukčiji način doživi destinaciju, pa samim time postoji različita samo-identifikacija turista i marke destinacije. Također, i Hankinson (2004) ističe da je marka destinacije iskustvena i naglašava važnost interakcije dionika i uvažava ulogu različitih interesnih skupina u kreiranju marke destinacije.

Marka destinacije sagledava se kroz kognitivni i osjećajni odnosno iskustveni element destinacije (Baloglu, McCleary, 1999). Iz tih razloga, kako navode Dredge i Jenkins (2003), teži se izgradnji prepoznatljivosti destinacije. Uvažavajući stavove Boo et al. (2009) izgradnja prepoznatljivosti destinacije temelji se na funkcionalnim, simboličkim i doživljajnim elementima destinacije. Kada se marka destinacije promatra kroz prizmu iskustva, tada se ona, sukladno mišljenju autora Murphy et al. (2000), može promatrati kroz dvije razine: infrastrukturu i okruženje destinacije. Slične stavove dijele Hu i Ritchie (1993) koji destinaciju sagledavaju kao multidimenzionalan skup različitih usluga i mogućnosti.

S obzirom na to da velik broj destinacija posjeduje slične karakteristike, potrebno je u cilju ostvarivanja konkurentske prednosti naglašavati jedinstvenost i specifičnost koju posjeduju pojedine destinacije. $U$ tom kontekstu javlja se potreba za izgradnjom marke destinacije, u čemu je utjecaj lokalnog stanovništva od posebnog značaja. Polazište u tome je uvažavanje i sagledavanje svijesti o marki destinacije te percipirane vrijednosti marke, što se reflektira na odanost prema marki destinacije kod lokalnog stanovništva. Navedeno, što se elaborira u nastavku, od interesa je za teoriju i praksu djelovanja na turističkom tržištu.

Svijest marke prezentira snagu prisutnosti marke u umu ciljane skupine osoba (Aaker, 1996). Također, svijest marke predstavlja srž marke zbog toga što se smatra početnom osnovom u kreiranju i povećanju vrijednosti marke (Gartner, Konecnik Ruzzier, 2011). U uslugama i turizmu, te posebno sagledavajući destinacije, svijest marke razmatra se kao glavna komponenta destinacije (Boo et al., 2009 prema Kim, Kim, 2005). Prisjećanje karakteristika i elemenata destinacije, pozitivna reputacija i prepoznatljivost destinacije te poznatost destinacije omogućavaju razvijanje svijesti marke destinacije (Boo et al., 2009; Kwun, Oh, 2004).

Percipirana vrijednost marke je koncept koji su razvili Aaker (1991) i Keller (1993). Percipirana vrijednost marke za destinaciju se povećava ako je više diferencirana od najbliže konkurencije (Gartner, Konecnik Ruzzier, 2011). Ekskluzivnost destinacije ili diferenciranost od konkurencije mora biti iskomunicirana i na turističkom tržištu dobro poznata, što u konačnici rezultira povećanjem vrijednost marke destinacije.

Dva su glavna pristupa u kontekstu marke i vrijednosti (Ruževičiūtė, Ruževičius, 2010). Prvi je financijski i odnosi se na promatranje marke i njene vrijednosti kako je sagledavaju poslovni subjekti. Poslovni subjekti razlikuju vrednovanje marke na temelju svih troškova vezanih za stvaranje i razvoj ili po osnovi vrednovanja marke cjenovnom usporedbom s drugim markama $u$ istoj kategoriji. Drugi pristup vezan je za potrošače i njihovu reakciju i ponašanje pri kupnji proizvoda ili usluga. Prema ovom pristupu vrijednost marke formira se u umu potrošača, iz čega proizlazi da je bitno 
znanje i iskustvo potrošača kao osnova za stvaranje diferencijalnog učinka o percepciji marke. Naime, potrošači u percipiranju vrijednosti marke uvažavaju više odrednica. Većina autora slaže se $u$ tome da se to odnosi na poznavanje marke, asocijacije uz marku, iskustvo marke, svijest o marki, imidž marke, kvalitetu marke, vrijednost marke i odanost marke (Keller, 1993; Boo et al., 2009; Gartner, Konečnik Ruzzier, 2011; Garcia et al., 2012; Pike, Page, 2014).

Odanost marke definira se kao privrženost potrošača prema marki (Aaker 1991), odnosno naglašava ponašanje potrošača kroz namjeru ponovnog odabira iste marke. Odanost marke često ukazuje na povoljan stav prema marki, kao i prema ponovljenom korištenju iste marke tijekom vremena (Rossiter, Percy, 1987). U kontekstu destinacije odanost marke predstavlja ponovni odabir turista pri izboru destinacije (Konecnik, Gartner, 2007), kao i povoljan stav te pozitivnu komunikaciju prema drugim budućim posjetiteljima (Im et al., 2012).

$\mathrm{Na}$ odanost marke destinacije posebni utjecaj dolazi od lokalnog stanovništva. Lokalno stanovništvo odanost prema marki destinacije manifestira lojalnošću prema destinaciji, širenjem pozitivnih informacija o kvaliteti života u destinaciji, poticanjem drugih na boravak i/ili posjetu destinaciji.

Više autora ukazuje da upravo percepcija lokalnog stanovništva, posebno onog zaposlenog u turizmu, ima značajan utjecaj na stav o marki turističke destinacije (Chuang, 2015). Braun et al. (2013) razmatraju ulogu lokalnog stanovništva tako da je lokalno stanovništvo integrirani dio kreirane marke turističke destinacije. Navedeno stoga što je lokalno stanovništvo u interakciji s ostalim dionicima. Smatra se da je iznimno važno da se uvažava percepcija lokalnog stanovništva i smanje svi negativni stavovi lokalnog stanovništva. Naime, ako lokalno stanovništvo osjeća pripadnost prema destinaciji i identificira se s destinacijom u kojoj živi, vjerojatno je da će potom biti gostoljubivo prema posjetiteljima (Choo et al., 2011). Gostoljubivost lokalnog stanovništva ogleda se u pomaganju i dijeljenju iskustva i znanja s posjetiteljima.

Lokalno stanovništvo kroz pozitivnu percepciju vrijednosti destinacije promatra istu kao logičan i dobar odabir za život. Pri tome lokalno stanovništvo uspoređuje dobrobiti i pozitivne strane života u destinaciji s troškovima življenja u njoj (Liu et al., 2015). Lokalno stanovništvo procjenjuje odnos kulturne baštine, događaja, turističke atrakcije i infrastrukture na percepciju i imidž marke destinacije (Folgado-Fernández, Hernández-Mogollón, 2015). Iz navedenog proizlazi da lokalno stanovništvo poznavanjem odnosa troškova i vrijednosti koje destinacija pruža razvija pozitivan stav i pridonosi dobrom imidžu destinacije. Dakle, identifikacija lokalnog stanovništva s destinacijom rezultira njihovom odanošću prema njoj.

$\mathrm{Na}$ tim teorijskim osnovama postavljen je konceptualni model istraživanja koji obuhvaća tri odrednice i njihovu vezu (shema 1). 
Shema 1. Konceptualni model istraživanja

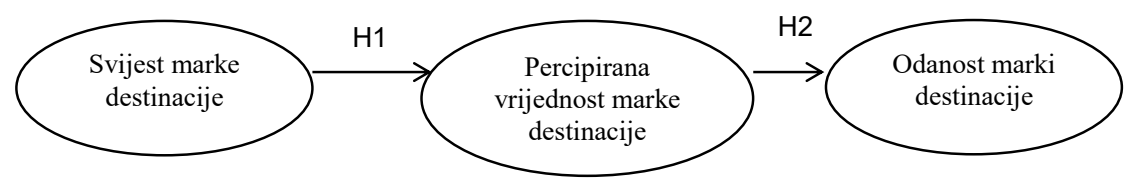

Percipirana vrijednost marke destinacije ovisi o percipiranoj ravnoteži između cijene i korisnosti (Lassar et al., 1995). Aaker (1996) je utvrdio da, ako marka pruža dobru vrijednost za novac, postoje razlozi za odabir te marke u odnosu na konkurenciju.

Kim i Kim (2005) smatraju da je izvorište percipirane vrijednosti marke destinacije u svijesti o marki destinacije. Navedeni stavovi nalaze potvrdu u postavkama Kellera (1993) kao nosioca znanstvene misli o markama koji ukazuje da će destinacija biti uspješna kada se razvije svijest o marki destinacije. Svijest o marki razvija se ne samo kod turista već i kod lokalnog stanovništva. Što je destinacija prepoznatljivija i ima dobru reputaciju među lokalnim stanovništvom, to isto lokalno stanovništvo smatrat će da postoji više pozitivnih strana za život u toj destinaciji, uzimajući u obzir buduće turističke efekte. Uvažavajući navedene postavke predlaže se sljedeća hipoteza istraživanja:

H1: Svijest o marki destinacije pozitivno utječe na percipiranu vrijednost marke destinacije.

Odanost prema marki je srž tržišne vrijednosti marke (Aaker, 1991), a odanost prema marki rezultanta je percipirane vrijednosti marke. Oliver (1980) također smatra da je percipirana vrijednost marke ključna u stvaranja odanosti prema njoj. Proizlazi da odanost prema destinaciji predstavlja namjeru ponovljene kupnje, odnosno ponovnog dolaska u destinaciju, ali i, kako to ističu Yoon i Uysal (2005), kao osjećaj pripadnosti određenoj destinaciji, odnosno želju da se nastavi živjeti u toj destinaciji. Grupa autora smatra da će, što je veća percipirana vrijednost marke destinacije, postojati veća razina odanosti određenoj destinaciji (Boo et al., 2009). Stoga, ako je marka destinacije percipirana da pruža vrijednost svojim potrošačima u promatranom slučaju lokalnom stanovništvu, to će postojati veća želja toga lokalnoga stanovništva da ostane u destinaciji, odnosno, da osjećaju pripadnost destinaciji i pridonose razvoju marke destinacije. Temeljem prethodnoga predlaže se sljedeća hipoteza:

H2: Percipirana vrijednost marke destinacije pozitivno utječe na odanost prema marki destinacije.

\section{ISTRAŽIVANJE PERCIPIRANE VRIJEDNOSTI MARKE DESTINACIJE KOD LOKALNOG STANOVNIŠTVA ZAPOSLENOG U TURIZMU}

\section{1 Metodologija}

Istraživanje je provedeno klasičnim anketnim upitnikom u više gradova u Hrvatskoj. Obuhvaćeni gradovi su: Mali Lošinj, Poreč, Zadar, Split, Knin, Osijek i Dubrovnik. Kriterij za odabir gradova temeljio se na stupnju razvoja turističke ponude te broju noćenja u pojedinim destinacijama. Mali Lošinj, Dubrovnik i Poreč imaju uzastopce duži niz godina broj noćenja u porastu, dok u posljednje 
vrijeme izniman rast bilježe Split i Zadar (DZS, 2016). Pored spomenutih etabliranih destinacija u uzorak su ušle i destinacije Knin i Osijek. Odabir ovih dviju destinacija bazirao se na nižoj stopi razvoja turističke ponude, ali velikom potencijalu razvoja (Hrvatski turizam, 2015).

Pitanja u anketnome upitniku bazirala su se na prethodnim istraživanjima. Tako su pitanja vezana za svijest marke preuzeta od Im et al. (2012), Boo et al. (2009), Liu et al. (2015), za percipiranu vrijednost marke od Boo et al. (2009), Liu et al. (2015), a za odanost marke od Im et al. (2012), Liu et al. (2015). Sva pitanja koristila su 7-stupanjsku Likertovu skalu koja se kreće od 1 „U potpunosti se ne slažem," do 7 „U potpunosti se slažem“. Pitanja su se u odnosu na prethodna istraživanja koja su se bazirala na percepciji turista prilagodila istraživanju i korištenoj perspektivi lokalnog stanovništva. Pored pitanja vezanih uz percipiranu vrijednost marke od strane potrošača, u upitniku su postavljena i demografska pitanja.

Istraživanje se provodilo u razdoblju od prosinca 2016. do svibnja 2017. godine. Sakupljeno je 114 odgovora lokalnog stanovništva zaposlenog u turističkim zajednicama i turističkim agencijama. Analiza je napravljena pomoću statističkog programa SPSS ver 21.

\subsection{Uzorak istraživanja}

U istraživanju je sudjelovalo 114 ispitanika koji su zaposleni u turističkim zajednicama i turističkim agencijama u sljedećim gradovima: Mali Lošinj, Split, Poreč, Knin, Osijek, Zadar i Dubrovnik. Struktura ispitanika po gradovima prikazana je u tablici 1.

Tablica 1. Struktura ispitanika po gradovima

\begin{tabular}{|l|c|r|}
\hline \multicolumn{1}{|c|}{ Grad } & Broj ispitanika & \multicolumn{2}{c|}{ Postotak } \\
\hline Split & 43 & 37,7 \\
\hline Osijek & 16 & 14,0 \\
\hline Zadar & 14 & 12,3 \\
\hline Dubrovnik & 13 & 11,4 \\
\hline Mali Lošinj & 13 & 11,4 \\
\hline Poreč & 12 & 10,6 \\
\hline Knin & 3 & 2,6 \\
\hline Ukupno & 114 & 100,0 \\
\hline \multicolumn{2}{|c|}{} \\
\hline
\end{tabular}

Ispitanici su uglavnom ženskog spola (67\%), imaju od 30 do 39 godina (38,6\%), zaposleni su (55,3\%) i rade u turističkoj agenciji (57,9\%) te imaju od 6 do 10 godina radnog iskustva (26,3\%). Uzorak ima karakteristike namjernog uzorka koji čine osobe koje rade u turističkim zajednicama i turističkim agencijama koje po svom mjestu stanovanja spadaju u kategoriju lokalnog stanovništva. Izbjeglo se ispitivanje hotelskog osoblja koje ima karakteristike sezonskog zapošljavanja, koje najčešće samo boravi u svojstvu zaposlenika u destinaciji. Ostale karakteristike ispitanika prikazane su u tablici 2. 
Tablica 2. Struktura ispitanika po demografskim karakteristikama

\begin{tabular}{|c|c|}
\hline Karakteristika & Postotak ispitanika \\
\hline Spol & 33,3 \% muški, 66,7 \% ženski \\
\hline Dob & $\begin{array}{c}19-24 \text { godina }=2,6 \% \\
25-29 \text { godina }=22,8 \% \\
30-39 \text { godina }=38,6 \% \\
40-49 \text { godina }=16,7 \% \\
50-59 \text { godina }=14,9 \% \\
60 \text { i stariji }=4,4 \%\end{array}$ \\
\hline Mjesto zaposlenja & $\begin{array}{l}\text { Turistička agencija }=57,9 \% \\
\text { Turistička zajednica }=42,1 \%\end{array}$ \\
\hline Status zaposlenja & $\begin{array}{c}\text { Voditelj }=36,8 \% \\
\text { Zaposlenik }=55,3 \% \\
\text { Ostalo }=7,9 \%\end{array}$ \\
\hline Radno iskustvo & $\begin{array}{c}\text { Manje od } 1 \text { godine }=3,5 \% \\
1-5 \text { godina }=27,2 \% \\
6-10 \text { godina }=26,3 \% \\
11-20 \text { godina }=25,4 \% \\
21-30 \text { godina }=7 \% \\
\text { Više od } 31 \text { godinu }=10,5 \%\end{array}$ \\
\hline
\end{tabular}

Izvor: rezultati istraživanja

\section{ANALIZA REZULTATA ISTRAŽIVANJA}

\section{1 Procjena pouzdanosti i valjanosti mjernih ljestvica}

U cilju provjere postavljenih hipoteza te kako bi se provjerila pouzdanost korištenih mjernih ljestvica napravljena je eksplorativna faktorska analiza (EFA). Korištena je metoda glavnih faktora (engl. Princpial component analysis) uz oblimin rotaciju te Kaiser normalizaciju. Nakon provedene faktorske analize identificirana su tri faktora: svijest marke, percipirana vrijednost marke i odanost marki. Prema Hair et al. (2010) u provedenoj faktorskoj analizi Kaiser-Meyer-Olkin (KMO) mjera primjerenosti uzorkovanja je primjerena $(0,904)$, tj. iznad prihvatljivog kriterija od 0,7, te je Bartlettov test sferičnosti statistički značajan. Navedeno ukazuje da je moguće nastaviti analizu korištenjem identificiranih triju faktora. $U$ analizi su se sva faktorska opterećenja manja od 0,3 zanemarila (Field, 2009), te se jedna tvrdnja koja se 
učitala na dva faktora izlučila iz daljnje analize. Identificirana tri faktora objašnjavanju 71,307 \% varijance u rezultatima. Analiza pouzdanosti, tj. Cronbach alpha vrijednosti, sugeriraju da se može nastaviti s analizom jer se vrijednosti kreću iznad 0,7, kako sugerira Nunnally (1967). Naime, najniža vrijednost je 0,837. Komunalitete pojedinih tvrdnji također su iznad prihvatljivog nivoa od 0,5 (Field, 2009), najniža razina iznosi 0,610. Rezultati provedene analize, kao i faktorska opterećenja, prikazana su u tablici 3.

Tablica 3. Faktorska analiza i analiza pouzdanosti

\begin{tabular}{|c|c|c|c|}
\hline \multirow[b]{2}{*}{ Tvrdnje } & \multicolumn{3}{|c|}{ Faktori } \\
\hline & $\begin{array}{l}\text { Svijest } \\
\text { marke }\end{array}$ & $\begin{array}{c}\text { Percipirana } \\
\text { vrijednost } \\
\text { marke }\end{array}$ & $\begin{array}{l}\text { Odanost } \\
\text { marki }\end{array}$ \\
\hline $\begin{array}{l}\text { Prepoznajem ovu destinaciju kao turističku } \\
\text { destinaciju među ostalim destinacijama. }\end{array}$ & 0,861 & & \\
\hline $\begin{array}{l}\text { Ova destinacija ima dobro (prepoznatljivo) ime i } \\
\text { reputaciju (na dobrom je glasu). }\end{array}$ & 0,823 & & \\
\hline Mogu se brzo sjetiti karakteristika ove destinacije. & 0,784 & & \\
\hline Ova destinacija je vrlo poznata. & 0,740 & & \\
\hline $\begin{array}{c}\text { Ova destinacija ima razumne cijene turističkih } \\
\text { usluga. }\end{array}$ & & 0,799 & \\
\hline Ova destinacija je ekonomičan odabir za život. & & 0,937 & \\
\hline $\begin{array}{c}\text { Ova destinacija je dobar odabir. Isplati se živjeti u } \\
\text { ovoj destinaciji. }\end{array}$ & & 0,812 & \\
\hline $\begin{array}{l}\text { Troškovi života ove destinacije nisu ništa u odnosu } \\
\text { na dobrobiti koje primam. }\end{array}$ & & 0,815 & \\
\hline $\begin{array}{l}\text { Ova destinacija bila bi moj prvi odabir (koji } \\
\text { preferiram) za živjeti. }\end{array}$ & & & 0,827 \\
\hline $\begin{array}{l}\text { Ova turistička destinacija pruža više pogodnosti za } \\
\text { život u odnosu na neku drugu destinaciju. }\end{array}$ & & & 0,714 \\
\hline Imam namjeru biti u ovoj destinaciji idućih 5 godina. & & & 0,887 \\
\hline $\begin{array}{l}\text { Snažno bih preporučio ovu destinaciju nekome tko } \\
\text { traži savjet o tome koju destinaciju posjetiti. }\end{array}$ & & & 0,770 \\
\hline Volim živjeti u ovoj destinaciji. & & & 0,865 \\
\hline Odan/a sam ovoj destinaciji. & & & 0,815 \\
\hline Cronbach alpha & 0,837 & 0,882 & 0,913 \\
\hline Postotak objašnjene varijance & $15,718 \%$ & $9,165 \%$ & $46,425 \%$ \\
\hline Karakteristični korijen & 2,201 & 1,283 & 6,499 \\
\hline Prosječna ocjena & 5,850 & 4,465 & 5,257 \\
\hline
\end{tabular}


Faktori dobiveni eksplorativnom faktorskom analizom koristili su se prilikom testiranja hipoteza.

\section{2 Testiranje hipoteza}

$U$ cilju testiranja hipoteza koristile su se linearne regresijske analize. $U$ prvome promatranome modelu promatra se kao zavisna varijabla percipirana vrijednost marke, a kao nezavisna svijest marke. Postotak objašnjene varijance rezultata (korigirani $R^{2}$ ) relativno je nizak, odnosno iznosi $2,9 \%$. Spomenuto implicira da postoje još neki drugi faktori koji utječu na percipiranu vrijednost marke turističke destinacije pored same svijesti marke. Rezultati analize za zavisnu varijablu percipirana vrijednost marke prikazani su u tablici 4.

Tablica 4. Regresijska analiza za percipiranu vrijednost marke kao zavisnu varijablu

\begin{tabular}{|l|c|c|c|}
\hline & B & Beta & T-vrijednost \\
\hline Konstanta & 3,033 & & 3,749 \\
\hline Svijest marke & $0,277(0,132)$ & 0,194 & $2,094^{* *}$ \\
\hline Broj ispitanika & 114 & \\
\hline R2 & \multicolumn{3}{|c|}{0,038} \\
\hline Korigirani R2 & \multicolumn{3}{|c|}{$4,383^{* *}$} \\
\hline F-vrijednost & \multicolumn{3}{|c|}{} \\
\hline
\end{tabular}

Napomene: Metoda selekcije = Enter metoda, Standardna pogreška navedena je u zagradama,

** $p<0,05$

Izvor: rezultati istraživanja

Analiza rezultata linearne regresijske analize ukazuje na to da, iako je postotak objašnjene varijance rezultata relativno nizak, ipak postoji statistički značajan utjecaj svijesti marke na percepciju vrijednosti marke $(\beta=0,194)$.

U drugome promatranome modelu promatra se odanost marke kao zavisna varijabla, a percipirana vrijednost marke kao nezavisna varijabla. Postotak objašnjene varijance rezultata (korigirani $R^{2}$ ) iznosi 32,9\%. Rezultati analize za zavisnu varijablu odanost marke prikazani su u tablici 5. 
Tablica 5. Regresijska analiza za odanost marke kao zavisnu varijablu

\begin{tabular}{|l|c|c|c|}
\hline & B & Beta & T-vrijednost \\
\hline Konstanta & 3,555 & & 12,096 \\
\hline $\begin{array}{l}\text { Percipirana vrijednost } \\
\text { marke }\end{array}$ & $0,449(0,060)$ & 0,579 & $7,515^{* *}$ \\
\hline Broj ispitanika & 114 & \\
\hline R2 & \multicolumn{3}{|c|}{0,335} \\
\hline Korigirani R2 & \multicolumn{3}{|c|}{$56,477^{* *}$} \\
\hline F-vrijednost & \multicolumn{3}{|c|}{} \\
\hline
\end{tabular}

Napomene: Metoda selekcije $=$ Enter metoda, Standardna pogreška navedena je u zagradi,

${ }^{* *} p<0,05$

Izvor: rezultati istraživanja

Analiza rezultata linearne regresijske analize ukazuje da postoji statistički značajan utjecaj percipirane vrijednosti marke na odanost marke $(\beta=0,579)$.

\section{3 Diskusija o rezultatima istraživanja}

Na temelju rezultata istraživanja može se tvrditi da će, ako se poveća svijest marke kod lokalnog stanovništva, to pozitivno utjecati na percepciju vrijednosti marke kod njih. Naime, povećanjem svijesti marke kod lokalnog stanovništva otvara se nova dimenzija percepcije destinacije od strane tog istog stanovništva. Percepcija vrijednosti marke determinira izgradnju marke (Liu et al., 2015) te, kao što ističu Bašan et al. (2013), navedeno utječe na imidž destinacije. Provedenim istraživanjem na namjernom uzorku lokalnog stanovništva utvrđeno je da postoji izravna i pozitivna veza svijesti marke destinacije s povećanjem vrijednosti marke destinacije. Stoga se može prihvatiti $\mathrm{H} 1$ da svijest marke turističke destinacije pozitivno utječe na percepciju vrijednosti marke turističke destinacije.

U istraživanju grupe autora (Boo et al., 2009) utvrđeno je da se povećanjem percipirane vrijednosti marke povećava odanost prema određenoj turističkoj destinaciji. Istaknuti autori proveli su istraživanje na uzorku turista, dok se u predmetnom navedeno provjerava uvažavajući stavove lokalnog stanovništva. Predmetnim istraživanjem utvrđeno je da povećanje percipirane vrijednosti marke kod lokalnog stanovništva pozitivno utječe na odanost marke destinacije. Odanost prema marki destinacije očituje se u vidu emotivne povezanosti lokanog stanovništva s destinacijom i želje za nastavkom djelovanja u njoj te isticanjem njene vrijednosti kroz komunikaciju s dionicima na turističkom tržištu. Dakle, može se zaključiti da povećanje percepcije vrijednosti marke destinacije pozitivno utječe na odanost prema marki destinacije. Proizlazi da se može prihvatiti H2 da percipirana vrijednost marke turističke destinacije pozitivno utječe na odanost marki turističke destinacije.

Doprinos rada ogleda se u rezultatima istraživanja kojima je utvrđeno da kod lokalnog stanovništva postoji utjecaj svijesti marke destinacije na percipiranu vrijednost marke destinacije. Nadalje, utvrđeno je da se povećavanjem vrijednosti marke destinacije povećava i odanost prema marki 
destinacije. Drugim riječima, lokalno stanovništvo gradi svijest o marki, što pridonosi većem vrednovanju marke destinacije i, u konačnici, odanosti prema marki destinacije. Proizlazi da je lokalno stanovništvo spremno raditi i stvarati u destinaciji u kojoj živi i djeluje te da prenosi doživljaj destinacije na turiste. Potvrda takvih zaključaka nalazi se i u radu grupe autora (Kim et al., 2013) koji su utvrdili da se podizanjem odanosti prema destinaciji povećava razina zadovoljstva lokalnog stanovništva, kao i percepcija kvalitete života u destinaciji.

Završno, rezultati istraživanja ukazuju da lokalno stanovništvo ima značajnu ulogu u izgradnji marke turističke destinacije. Proizlazi da je vrijedno ulagati napore kako bi lokalno stanovništvo razvilo svijesti o marki destinacije, jer povećana svijesti o marki destinacije utječe na njeno vrednovanje, a povećano vrednovanje na jačanje odanosti prema marki destinacije. Rezultanta tog procesa je zadovoljstvo destinacijom i širenjem njenih vrijednosti u komunikaciji s turistima, što pojačava njihovu svijest o marki, posljedično njeno vrednovanje i odanost.

Spoznaje iz istraživanja imaju aplikativnu vrijednost. Ona se očituju u spoznajama o odrednicama razvoja odanosti marke destinacije kod lokalnog stanovništva s multiplikativnim učincima na razvoj destinacije. Pri tome je potrebno da odgovorni u destinacijama i kreatori turističkog razvoja donose odluke kojima se jača svijest o marki destinacije i neizravno percipirana vrijednost marke destinacije kod lokalnog stanovništva. Rezultanta takvih aktivnosti je jačanje reputacije i prepoznatljivosti te diferencijacije od drugih destinacija.

\section{ZAKLJUČAK}

Istraživanjem povezanosti svijesti marke, percipirane vrijednosti marke i odanosti marke destinacije kod lokalnog stanovništva pridonosi se shvaćanju i prepoznavanju uloge lokalnog stanovništva, posebice onoga zaposlenoga u turističkim zajednicama i turističkim agencijama, u izgradnji marke turističke destinacije. Smatra se da je potrebno proaktivno djelovanje svih dionika destinacije kako bi se izgradila marka turističke destinacije. Budući da postoje različiti dionici kreiranja marke turističke destinacije, nužno je usklađivanje njihovih različitih interesa. Jedan od ključnih dionika u tim procesima je lokalno stanovništvo. Lokalno stanovništvo svojom ulogom i aktivnostima pridonosi razvoju marke destinacije. Pri tome se spoznajama o kriterijima lokalnog stanovništva o razvoju svijesti, percipiranoj vrijednosti i odanosti marke destinacije osigurava osnova za razvoj marke destinacije.

Rezultati provedenog istraživanja potvrđuju hipoteze daje potrebno uvažavati lokalno stanovništvo i poduzimati aktivnosti u razvoju procesa koji polazište ima u izgradnji svijesti kojom se utječe na jačanje percepcije o vrijednosti i odanosti prema marki destinacije. Odanost kao ključna sastavnica $\mathrm{u}$ tom procesu očituje se u emotivnoj povezanosti te namjeri nastavka djelovanja lokalnog stanovništva s višestrukim učincima na razvoj turizma u destinaciji.

Provedeno istraživanje može se smatrati indikativnim radi ograničenja koja su uočena u samome istraživanju. Uzorak istraživanja je namjerni. Obuhvaća samo dio lokalnog stanovništva koje je zaposleno u turizmu i to one zaposlene u turističkim zajednicama i turističkim agencijama. Ako bi se uključilo i druge dionike u destinaciji, kao npr. zaposlene u ugostiteljstvu, u hotelijerstvu ili drugim djelatnostima povezanima uz turizam, moguće je da bi se došlo do drukčijih spoznaja 
uz percipiranu vrijednost i odanost marki destinacije. Navedeno ostavlja mogućnost za buduća istraživanja.

Ostao je i otvoren čitav niz područja istraživanja o marki destinacije. Neka pitanja su ostala otvorena, posebno ako se uvaži činjenica da na marku destinacije utječe čitav niz čimbenika. Svaki čimbenik ima određenu važnost za izgradnju i upravljanje markom destinacije, a u provedenom istraživanju uzeti su samo neki čimbenici i to na uzorku lokalnog stanovništva. Rezultati provedenog istraživanja na lokalnom stanovništvu donekle se razlikuju od rezultata istraživanja koja su provedena na uzorku turista, stoga navedeno otvara mogućnost za nova istraživanja. Pored toga, karakteristike pojedinih destinacija razlikuju se, što također utječe na rezultate istraživanja, te bi se moglo budućim istraživanjem i analizirati pojedine destinacije te njihove razlike. Sukladno navedenom u daljnjem istraživanju trebalo bi uključiti nove destinacije, ostale dionike i sastavnice koje determiniraju marke destinacije.

\section{ZAHVALA}

Ovaj rad financiran je sredstvima Sveučilišta u Rijeci za projekt ZP UNIRI 9/17.

\section{LITERATURA}

Aaker, D. A. (1991) Managing Brand Equity, New York. The free press.

Aaker, D. A. (1996) Building strong brands: Building, measuring, and managing brand equity, New York. The free press.

AMA, American marketing association, dostupno na:

https://www.ama.org/resources/Pages/Dictionary.aspx?dLetter=B (19.3. 2017.)

Baloglu, S., McCleary, K.W. (1999) "A Model of Destination Image Formation", Annals of Tourism Research, 26 (4), 868-97. https://doi.org/10.1016/S0160-7383(99)00030-4

Bašan, L., Bagarić, L., Lončarić, D. (2013) „Impact of Brand Recognition on Reinforcing the Destination's Image." U Janković, S., Smolčić Jurana, D. (ur.) Proceedings of 2nd International Scientific Conference: Tourismin Southern and Eastern Europe 2013: Crisis - a Challenge of Sustainable Tourism Development? pp. 87-100, Opatija, University of Rijeka Faculty of Tourismand Hospitality Management, Opatija

Blichfeldt, B. S. (2005) “Unmanageable Place Brands?”, Place Branding,1 (4), 388-401. https://doi.org/10.1057/palgrave. pb.5990036

Boo, S., Busser, J., Baloglu, S. (2009) "A model of customer-based brand equity and its application to multiple destinations", Tourism Management, 30 (2), 219-231. https://doi.org/10.1016/j.tourman.2008.06.003

Braun, E., Kavaratzis, M., Zenker, S. (2013) "My city-my brand: the different roles of residents in place branding", Journal of Place Management and Development, 6(1), 18-28. https://doi.org/10.1108/17538331311306087

Brent-Ritchie, J. B. (1998) The Branding of Tourism Destinations, Past Achievements and Future Challenges, Scopes and Limitations, edited by Peter Keller, Marrakech, Morocco

Choo, H., Park, S. Y., Petrick, J. F. (2011) "The influence of the resident's identification with a tourism destination brand on their behavior", Journal of Hospitality Marketing \& Management, 20(2), 198-216. https://doi.org/10.1080/19368623.2 011.536079 
Chuang, Y. H. (2015) "Exploring the Influence of Community Attachment on City Brand Attitudes: A Consideration of Tourism Impact", Marketing Review / Xing Xiao Ping Lun, 12(2), 189-213.

Dredge, D., Jenkins, J. (2003) “Destination place identity and regional tourism policy”, Tourism Geographies, 5 (4), 383-407. https://doi.org/10.1080/1461668032000129137

Državni zavod za statistiku (2016) „Hrvatska u brojkama 2016“, Zagreb.

Field, A. P. (2009) Discovering statistics using SPSS: (and sex, drugs and Rock'n'roll), SAGE Publications, Thousand Oaks, USA.

Folgado-Fernández, J. A., Duarte, P. A. O., Hernández-Mogollón, J. M. (2015) „Assessing the differentiated contribution of city resources to city brand image: Análisis de la diferente contribución de los recursos de la ciudad para el desarrollo de su imagen de marca", Tourism \& Management Studies, 11(1), 77-83

García, J. A., Gómez, M., Molina, A. (2012) "A destination-branding model: An empirical analysis based on stakeholders", Tourism Management, 33 (3), 646-661. https://doi.org/10.1016/j.tourman.2011.07.006

Gartner, W. C., Konečnik Ruzzier, M. (2011) “Tourism destination brand equity dimensions: Renewal versus repeat market”, Journal of Travel Research, 50 (5), 471-481. https://doi.org/10.1177/0047287510379157

Hair, JF. et al. (2010) Multivariate Data Analysis: a Global Perspective, 7e ed., Prentice Hall.

Hankinson, G. (2004) "Relational network brands: Towards a conceptual model of place brands", Journal of Vacation Marketing, 10 (2), 109-121. https://doi.org/10.1177/135676670401000202

Hrvatski turizam (2015) “Turizam u brojkama”, Ministarstvo turizma Republike Hrvatske.

Hu, Y., Ritchie, J. R. B. (1993) “Measuring destination attractiveness: A contextual approach”, Journal of Travel Research, 32, 25-34. https://doi.org/10.1177/004728759303200204

Im, H. H. et al. (2012) "Conceptualizing destination brand equity dimensions from a consumer-based brand equity perspective", Journal of Travel and Tourism Marketing, 29 (4), 385-403. https://doi.org/10.1080/10548408.2012.674884

Keller, K. L. (1993) "Conceptualizing, measuring, and managing customer-based brand equity”, The Journal of Marketing, 52 (1), 1-22. https://doi.org/10.1177/002224299305700101

Kim, H.-B., Kim, W.-G. (2005) “The relationship between brand equity and firms' performance in luxury hotels and chain restaurants", Tourism management 26 (4), 549-560. https://doi.org/10.1016/j.tourman.2004.03.010

Kim, K., Uysal, M., Sirgy, M. J. (2013) "How does tourismin a community impact the quality of life of community residents?", Tourism Management, 36, 527-540. https://doi.org/10.1016/j.tourman.2012.09.005

Konecnik, M., Gartner, W. C. (2007) "Customer-based brand equity for a destination", Annals of tourism research, 34 (2), 400-421. https://doi.org/10.1016/j.annals.2006.10.005

Kwun, J. W., Oh, H. (2004) "Effects of brand, price, and risk on customers' value perceptions and behavior alintentionsin the restauran tindustry", Journal of Hospitality and Leisure Marketing, 11(1), 31-49. https://doi.org/10.1300//150v11n01_03

Lassar, W., Mittal, B., Sharma, A. (1995) “Measuring customer-based brand equity”, Journal of consumer marketing, 12 (4), 11-19. https://doi.org/10.1108/07363769510095270

Liu, C. R., Liu, H. K., Lin, W. R. (2015) “Constructing customer-based museums brand equity model: The mediating role of brand value", International Journal of Tourism Research, 17 (3), 229-238. https://doi.org/10.1002/jtr.1979

Murphy, P., Pritchard, M. P., Smith, B., (2000) "The destination product and its impact on traveller perceptions", Tourism management, 21 (1), 43-52. https://doi.org/10.1016/50261-5177(99)00080-1

Nunnally, J. C. (1967) “Psychometric theory”, McGraw-Hill, New York.

Oliver, R. L. (1980) "A cognitive model of the antecedents and consequences of satisfaction decisions", Journal of marketing research, 17 (4), 460-469. https://doi.org/10.1177/002224378001700405

Pike, S., Page, S. (2014) "Destination Marketing Organizations and destination marketing: A narrative analysis of the literature", Tourism Management, 41, 1-26. https://doi.org/10.1016/j.tourman.2013.09.009

Rossiter, J. R., Percy, L. (1987) Advertising and promotion management. McGraw-Hill Book Company, New York. 
M. Jurišić, J. Dlačić, B. Grbac: Odrednice odanosti lokalnog stanovništva prema marki turističke... Zbornik Veleučilišta u Rijeci, Vol. 7 (2019), No. 1, pp. 1-15

Ruževičiūtè, R., Ruževičius, J. (2010) "Brand equity integrate devaluation model: consumer-based approach", Economics and Management, Macquarie University Ethics Review Committee, 1-393.

Yoon, Y., Uysal, M. (2005) "An examination of the effects of motivation and satisfaction on destination loyalty: a structural model", Tourism management, 26 (1), 45-56. https://doi.org/10.1016/j.tourman.2003.08.016 


\title{
DEFINING LOYALTY OF LOCAL INHABITANTS TOWARDS A TOURIST DESTINATION BRAND
}

\author{
Marijana Jurišić \\ Univ. spec. oec., PhD Student, Faculty of Tourism and Hospitality Management Opatija, University of \\ Rijeka, Primorska 42, 51410 Opatija, Croatia; e-mail: marijana1308@gmail.com

\section{Jasmina Dlačić} \\ PhD, Assistant Professor, Faculty of Economics and Business, University of Rijeka, Ivana Filipovića 4, \\ 51000 Rijeka, Croatia; e-mail: jasmina.dlacic@efri.hr
}

\section{Bruno Grbac}

PhD, Professor Emeritus, University of Rijeka, Croatia; e-mail: bruno.grbac.efri@gmail.com

\begin{abstract}
Successful development of a tourist destination is determined by proactive activities of all destinations' stakeholders. Besides tourists, the key tourist destination stakeholders are: employees in tourism, organizations in tourism as creators of tourism offer, local authorities, investors in tourist capacity and local inhabitants. The paper builds on the postulation that local inhabitants employed in tourism are the key ingredient that contributes to developing distinguishing elements of a destination and differentiates it from other tourist destinations. Based on previous findings and field research, the paper discusses how local inhabitants, especially ones that are employed in tourism, contribute to the development of a tourist destination brand. With that purpose in mind, field research has been conducted using the questionnaire on a purposive sample of several tourist destinations in Croatia. Brand awareness positively influences brand value of a tourist destination and consequently brand value positively influences brand loyalty of a tourist destination. All this contributes to the development of a tourist destination brand. The paper focuses only on several antecedents of building a tourist destination brand, and this is perceived as paper limitation. But, nonetheless, the paper has indicated new research streams that should be applied and, also, research results offer ideas for managerial structures in tourism that are focused on developing a tourist destination brand.
\end{abstract}

Key words: destination brand, local inhabitants, brand awareness, brand value, brand loyalty 